\title{
Research on Yichang Port Logistics Industrial Cluster under the Strategy of Yangtze River Economic Zone
}

\author{
Chuntao $\mathrm{Wu}^{1,}$, Peilin Deng ${ }^{2}$ \\ ${ }^{1}$ Hubei Three Gorges Polytechnic, Yichang, Hubei, 443000, China \\ ${ }^{2}$ Sichuan Vocational Technical College of Architecture, Deyang, Sichuan, 618000, China
}

Keywords: Yangtze River economic zone; logistics industrial cluster; supply chain; port logistics

\begin{abstract}
This paper puts forward suggestions that can accelerate the development of Yichang Port logistics industrial cluster to serve the strategy of Yangtze River economic zone through the analysis of current development situation and existing problems of Yichang Port logistics industrial cluster.
\end{abstract}

\section{Introduction}

As the country put forward that, the fundamental of the Yangtze river economic belt is to make the production data and production factors flow effectively in various places and links, and to make the regional development and industrial development more balanced, so as to establish a unified and orderly market system.

\section{Yangtze River Economic Zone and Logistics Construction}

In this process, the logistics industry will not only realize the expansion from the traditional services, like transport and warehousing, etc., to the fields of services, like multi-modal transport, the third party logistics and distribution services, etc., but also achieve the extension of other value-added links, such as packaging, processing, customer service, maintenance, etc. It can drive the development of related industries, like industry energy supplies, equipment sales and leasing, the logistics technology service, and it also can promote the logistics intensive industries of industry and commerce enterprise to enter to the industries, such as the regional distribution center of industry and commerce enterprise , after-sale service center, customer service center, processing center, etc.It can promote the formation of the logistics industry cluster, and further optimize the industrial structure, then promote the industrial upgrading, which will make the region and industry develop coordinately .

\section{Basic Development of Port Logistics in Yichang}

With the deepening of the national Yangtze river economic belt strategy, the social economy of Yichang has been developing steadily and healthily. Yichang GDP, fiscal revenue, total foreign trade export and other major economic indicators are the second among the whole province. The social and economic development in Yichang enhances, and the "Six-hundred-billion industry" like fine chemical, food and biological medicine, advanced equipment manufacturing, new materials, cultural tourism are put forward, and the growing economic power makes Yichang form the three gorges regional logistics industry cluster. In the next 5 to 10 years, as the jump of traffic environment, "regional transport hub city" will be formed, and the Hubei provincial deputy center city, as well as the city planning and positioning of the world hydropower and tourism city and the three gorges cluster city will make Yichang economic radiation ability to be significantly enhanced.

Due to the special location of Yichang, a large number of goods need to be re-exported through this area. This area becomes an ideal place for storage, consolidation and distribution of goods and transportation companies naturally. Regional advantage makes a large number of goods to be transported together, and make the former sporadic and scattered goods and enterprises together to 
form into scale, which lays the solid foundation for the development of logistics standardization, container, assemble, multi-modal transport, processing, and the form of the integration of supply chain and the cluster of industry. The development of Yichang port must transfer the location advantage into industrial advantage, and carry on the layout of the ports along the Yangtze, as well as the transfer of the infrastructure construction and the construction of corresponding transit services. It also need to have the foresight to invest in port, wharf, highway, railway, logistics enterprises, and to use the geographical advantage to build a thriving industry cluster. The planned port operation area of Yichang is shown in table 1.

Table 1 The Plan of the function and throughput of Yichang port operation area

\begin{tabular}{c|c|c}
\hline The main operation areas & Port functions & Trafficability \\
\cline { 3 - 3 } (Ten thousand tons ) \\
\hline Xiakou operation area & Coal, ore, bulk cargo & 2500 \\
\hline Taipingxi operation area & $\begin{array}{c}\text { bulk cargo, roll-roll } \\
\text { shipment }\end{array}$ & 2500 \\
\hline Maoping operation area & Containers, bulk cargo & 2500 \\
\hline Baiyang operation area & $\begin{array}{c}\text { Integrated logistics } \\
\text { transport }\end{array}$ & 1800 \\
\hline Yunchi operation area & $\begin{array}{c}\text { Integrated logistics } \\
\text { transport }\end{array}$ & 3500 \\
\hline Tianjiahe operation area & Chemicals, bulk cargo & 3300 \\
\hline Honghuatao operation area & Containers, bulk cargo & 1500 \\
\hline Zhicheng operation area & Coal, bulk cargo & 4800 \\
\hline Huaqiao operation area & $\begin{array}{c}\text { passenger } \\
\text { transport,Containers }\end{array}$ & 1500 \\
\hline Qixingtai operation area & breakbulk, bulk cargo & 2500 \\
\hline Yaojia port operation area & Containers, bulk cargo & 2500 \\
\hline (Binjiang operation area) & passenger transport & 2 Million people \\
\hline Total(Cargo capacity) & & 28900 \\
\hline
\end{tabular}

\section{Choice of Port Logistics Industry Cluster Mode in Yichang}

The main influencing factors of logistics industry cluster formation are natural environment, geographical conditions, traffic conditions, infrastructure, etc., and every influence factors is mutual influenced and interacted. It cannot only emphasized one aspect when analyzing, and measuring, but from the strategy and the systematical perspective. Analytic hierarchy process (ahp) will have the multiple comparison among the influence factors at the same level, and then the algorithm at the former level satisfies the comprehensive measurement of factors, which makes it more realistic to choose for the development of the regional logistics industry cluster pattern based on the analysis of which factors causes the sever influence on the logistics industry cluster .

According to the analysis of influencing factors of logistics industrial cluster, a hierarchical structure diagram of influencing factors of logistics industrial cluster can be constructed, as shown in figure 1. 


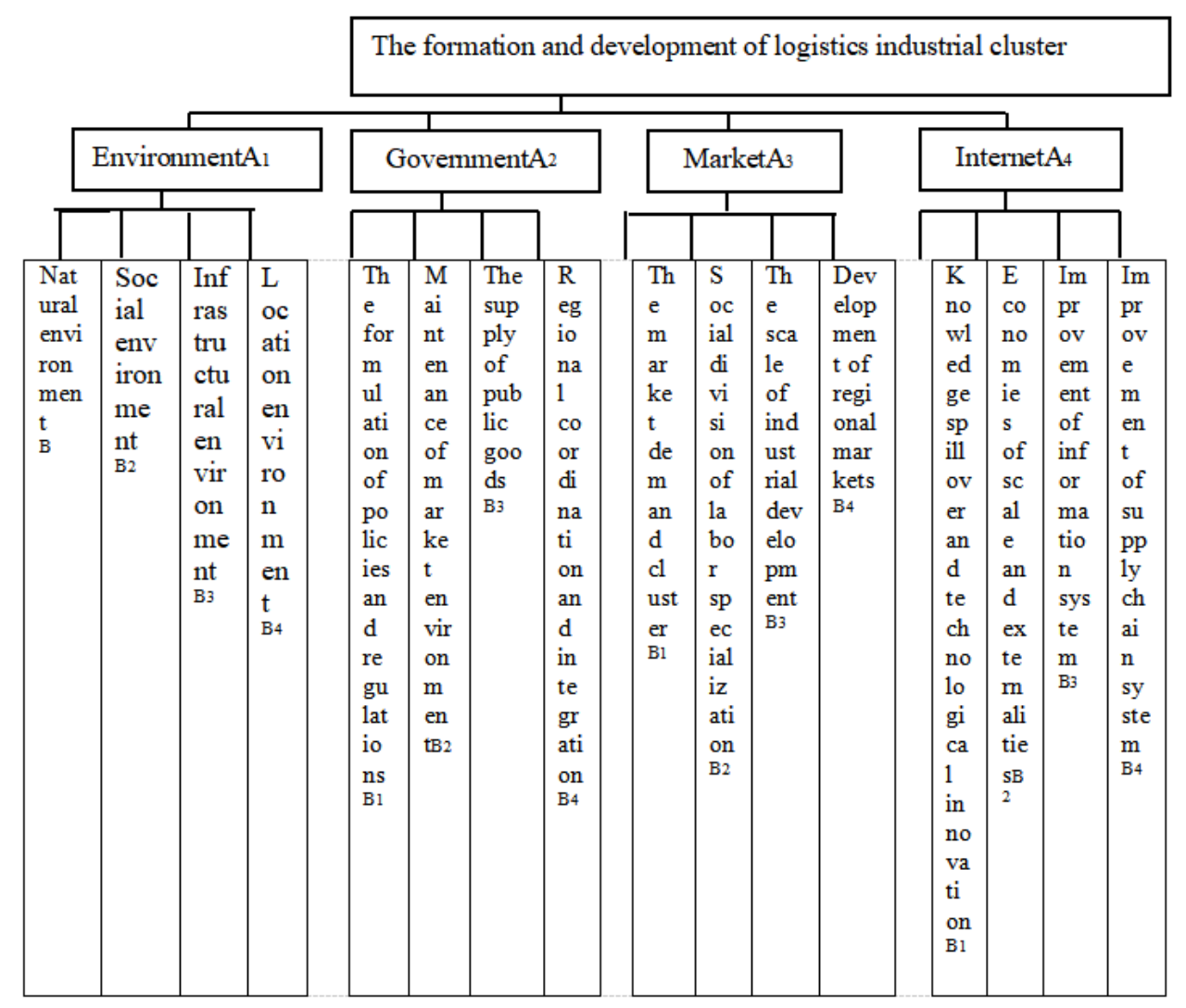

Figure 1. The hierarchical structure of influencing factors of logistics industrial cluster

Compare the contribution of the two factors to the overall goal, and construct the comparison matrix. Starting from the second floor of the hierarchical structure model, for every factors at the same layer belonging to the last layer, qualify the importance of each index with paired comparison and $1 \sim$ 9 scaling method. Construct two comparative judgment matrix, until to the bottom layer. The meaning of 1-9 scale in the construction of pairwise judgment matrix is shown in table 2:

Table 2. The meaning of scale 1 to 9

\begin{tabular}{c|c}
\hline scale & meaning \\
\hline 1 & The two indicators are equally important \\
\hline 3 & The former is slightly more important than the latter \\
\hline 5 & The former is significantly more important than the latter \\
\hline 7 & The former is much more important than the latter \\
\hline 9 & The former is more important than the latter \\
\hline $\begin{array}{c}\text { recipr } \\
\text { ocal }\end{array}$ & $\begin{array}{c}\text { Compared with factor I and j, the judgment matrix aij is obtained, so the } \\
\text { judgment of factor j compared with factor I is aji=1/aij }\end{array}$ \\
\hline
\end{tabular}

For the selection of scale 1 to 9, we can use Delphi method and ask relevant experts to evaluate it. The following is the assignment data and calculation results of the simulated expert scorea, as shown in table 3-4. 
Table 3. Pairwise comparison matrix and calculation: evaluation index of influencing factors of logistics industry cluster

\begin{tabular}{c|c|c|c|c}
\hline $\begin{array}{c}\text { initial } \\
\text { matrix }\end{array}$ & A1 & A2 & A3 & A4 \\
\hline A1 & 1 & 2 & 4 & 3 \\
\hline A2 & $1 / 2$ & 1 & 3 & 3 \\
\hline A3 & $1 / 4$ & $1 / 3$ & 1 & 2 \\
\hline A4 & $1 / 3$ & $1 / 3$ & $1 / 2$ & 1 \\
\hline and & $25 / 12$ & $11 / 3$ & $17 / 2$ & 9 \\
\hline
\end{tabular}

\begin{tabular}{c|c|c|c|c|c}
\hline $\begin{array}{c}\text { The adjusted } \\
\text { matrix }\end{array}$ & A1 & A2 & A3 & A4 & Weight (average) \\
\hline A1 & $12 / 25$ & $6 / 11$ & $8 / 17$ & $3 / 9$ & 0.457 \\
\hline A2 & $6 / 25$ & $3 / 11$ & $6 / 17$ & $3 / 9$ & 0.300 \\
\hline A3 & $3 / 25$ & $1 / 11$ & $2 / 17$ & $2 / 9$ & 0.138 \\
\hline A4 & $4 / 25$ & $1 / 11$ & $1 / 17$ & $1 / 9$ & 0.105 \\
\hline and & 1 & 1 & 1 & 1 & 1 \\
\hline
\end{tabular}

Table 4. The influencing factors of logistics industry cluster are in single order

\begin{tabular}{c|c|c|c|c|c|c|c|c|c}
\hline & B1 & B2 & B3 & B4 & & B1 & B2 & B3 & B4 \\
\hline \multicolumn{3}{c|}{ a)Environmental index ranking } & \multicolumn{5}{c|}{ c)Market index ranking } \\
\hline B1 & 1 & 5 & 6 & $1 / 3$ & B1 & 1 & 5 & 4 & 8 \\
\hline B2 & $5 / 1$ & 1 & 2 & $6 / 1$ & B2 & $1 / 5$ & 1 & $1 / 2$ & 4 \\
\hline B3 & $1 / 6$ & $1 / 2$ & 1 & $1 / 8$ & B3 & $1 / 4$ & 2 & 1 & 5 \\
\hline B4 & 3 & 6 & 8 & 1 & B4 & $1 / 8$ & $1 / 4$ & $1 / 5$ & 1 \\
\hline Weight & 0.297 & 0.087 & 0.053 & 0.563 & Weight & 0.597 & 0.140 & 0.124 & 0.050 \\
\hline \multicolumn{2}{|c|}{ b)Governmental index ranking } & & & d)Internet index ranking & \\
\hline B1 & 1 & $1 / 3$ & 5 & 8 & B1 & 1 & 3 & $1 / 5$ & 1 \\
\hline B2 & 3 & 1 & 7 & 9 & B2 & $1 / 3$ & 1 & $1 / 8$ & $1 / 3$ \\
\hline B3 & $1 / 5$ & $1 / 7$ & 1 & 2 & B3 & 5 & 8 & 1 & 5 \\
\hline B4 & $1 / 8$ & $1 / 9$ & $1 / 2$ & 1 & B4 & 1 & 3 & $1 / 5$ & 1 \\
\hline weight & 0.303 & 0.573 & 0.787 & 0.046 & weight & 0.151 & 0.060 & 0.638 & 0.151 \\
\hline
\end{tabular}

It can be seen from the above analysis results, among the influence factors of port logistics industry cluster in Yichang, the influence of regional environment on the formation of the logistics industry 
cluster is the greatest, and then it is the government's, and market and cluster network factors follow up. According to the forces sizes of different factors, they are in line with the power of the regional logistics industry cluster development mode, so in the formation and development process of yichang port logistics industry cluster, it should make full use of the area's unique environmental conditions, and seize the opportunity of the Yangtze River economic belt development strategy. Through the government's policy guidance and support, strengthen the infrastructure construction, establish comprehensive transportation system, develop logistics service function, strengthen personnel training, and provide more preferential policies for the enterprise. And convert the location advantage into industrial advantage as soon as possible, then build the core competitiveness.

\section{Development Measures of Port Logistics Industrial Cluster in Yichang}

Yichang port logistics industrial cluster should be linked up and down to form a supply chain development model. The basic model of the supply chain is a network structure. Every enterprise is a node on the Internet. As a transfer station of economic communication, Yichang port plays a very important role in the recombination of the whole supply chain and value chain, and it is a key link in the whole supply chain. Figure 2 is a simplified structure diagram of the new supply chain management model centered on ports.

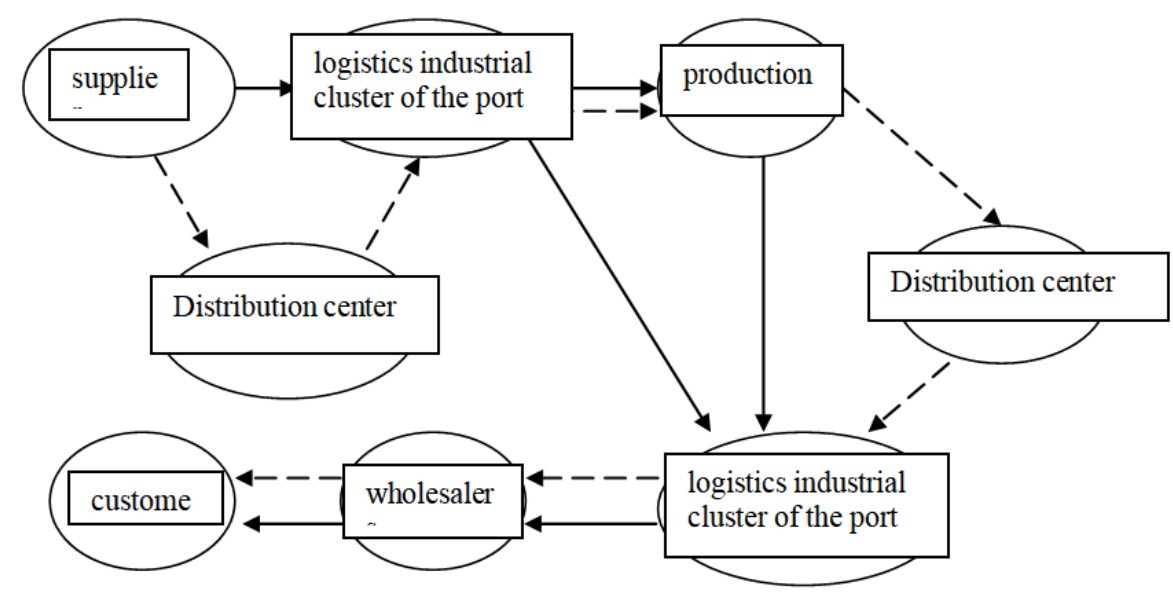

Fig. 2. Port - centric supply chain management model

The formation of Yichang port needs to be carried out from the following three aspects:
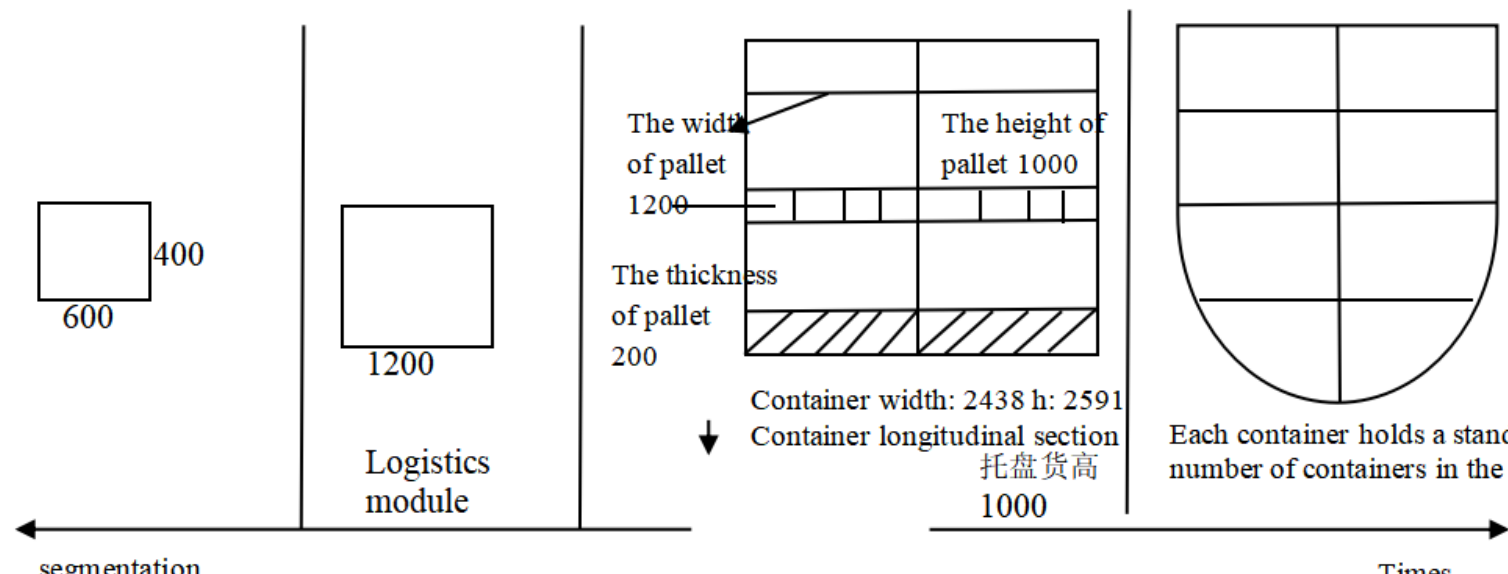

Each container holds a standard number of containers in the cabin

segmentation

Times

Logistics base module

Figure 3 Logistics module serialization 


\subsection{Establish unified logistics service standards}

Logistics standardization construction is the basis and core of circulation, which can minimize transaction costs, reduce logistics links and logistics costs, and guarantee logistics quality and benefits. The primary content of logistics standardization is complete, reasonable and standardized system, coordinating various strengths, such as suppliers, manufacturers, distributors, to develop a unified universal standard, mainly including terms related to logistics, logistics standard unit of measurement standard, the logistics base module size, etc. Logistics module serialization is shown in FIG. 3, and the unit is $\mathrm{mm}$.

\subsection{Establish the public information platform for logistics industry clusters}

At present, one of the "bottleneck" problems in the development of logistics industry clusters are the lack of public information exchange platform within clusters, and the supply chain of enterprises within and outside clusters cannot be effectively integrated [5]. In order to improve the quick response between enterprises and meet the personalized needs of customers, the information platform of logistics industry cluster is established.Logistics public information platform based on Internet technology, is a information platform, on which provides the sources sharing services, such as logistics information, technology, equipment,etc., and has the resources like integrating the logistics information in each links of the supply chain, logistics supervision, logistics technology and equipment, etc. And it also faces the society to provide information services, management services, technical service and trading services. Logistics cluster information platform should actively introduce barcode technology, EDI technology, Internet of things technology and so on. Through the application of logistics information technology, we can solve the problems of material management disorder, and code, print bar code labels for the material, as well as have the material tracking management. Also we can effectively control the production, and collect data and establish the relevant information files, then set up the big data supply chain; Formulate unified EDI data standards, improve the software and hardware facilities required for EDI system, circulate the upstream and downstream information of supply chain, and integrate them. The public information platform of its logistics cluster is shown in figure 4.

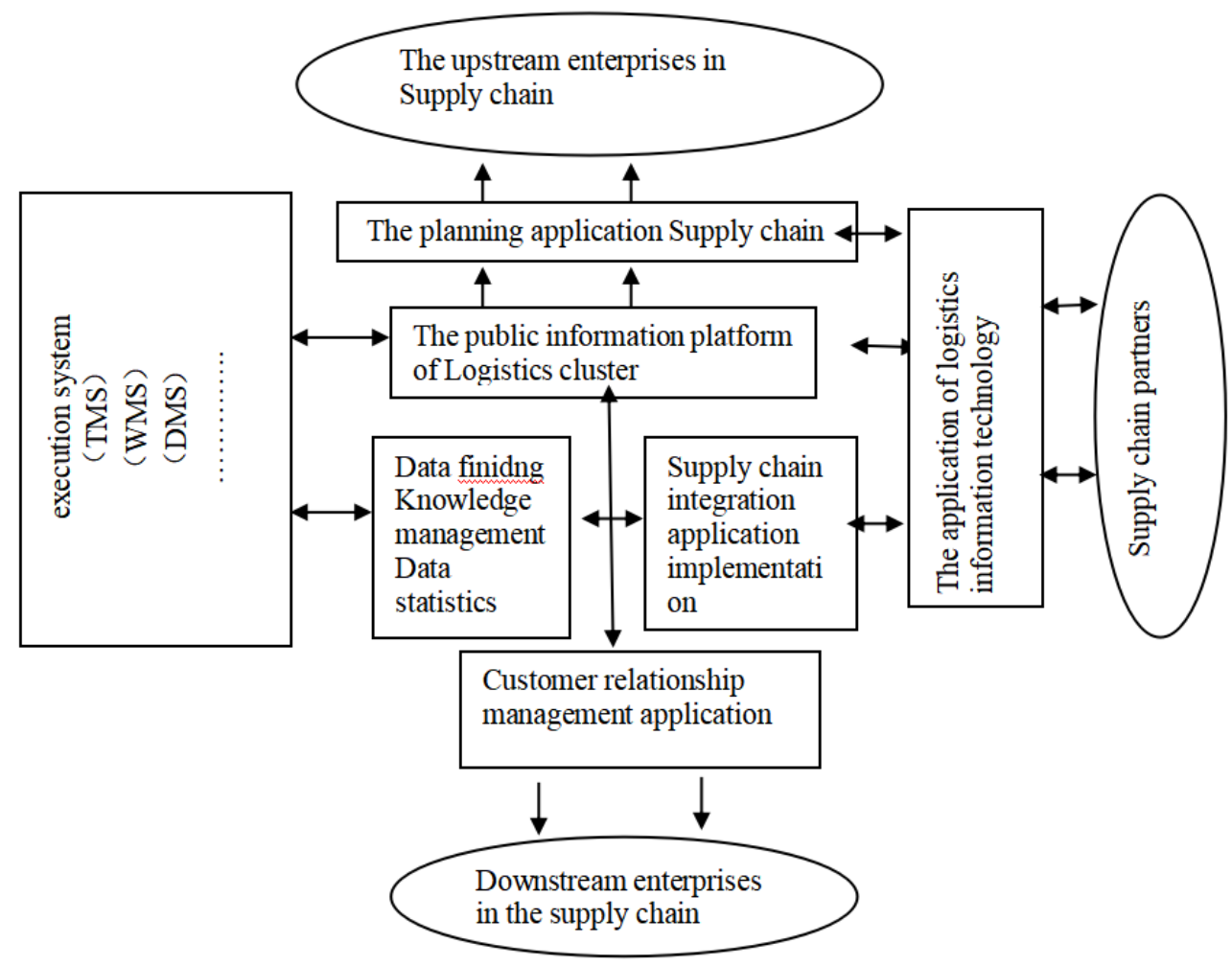

Figure 4. The construction of logistics industry cluster information platform 


\subsection{Integrate logistics resources and realize logistics integration}

In order to integrate logistics resources into Yichang port, it is necessary to cultivate core operating enterprises of the port, expand logistics service functions, develop brand logistics, and innovate management system, which can be implemented from the following aspects:

Through resource integration and strategic cooperation, Yyichang port should become a core enterprise and expand logistics service functions. To broaden the logistics services, the modern communication technology and automation of the transport, storage technology should be adopted, and every modern mode of transportation to the port should be gathered, so as to transport the goods to the vast hinterland of Yichang port, and make the port to be the transportation hub, and to give its full play to transfer function. Then taking the modern transport as the main line, the warehousing, packaging, distribution, processing, information services, and other integrated logistics function, make the port connotation from hub to a wider, higher-level logistics network node. Final goods not only can flow unimpeded on logistics network, and according to the requirements of customers, for customer service at the same time, develop distribution processing services, through processing services, make the goods in the port value-added during the transfer process, so as to improve the port function and achieve the goal of being the development of hinterland economy.

Through resource integration and strategic cooperation, Yichang port should strengthen infrastructure construction and realize the linkage between the port areas. In order to achieve the transit transport functions of Yichang port logistics, the development of multimodal transport should be regards as the orientation, speed up the docking with the port of highway, aviation, railways and other infrastructure construction, and adhere to the principle of using waterway when it is appropriate for "water", using highway when it is appropriate for "roads", and using railway when it is appropriate for "trains". Try the best to create the integration of highway and railway and modern integrated transport systems, and provide the solid guarantee for Yichang three gorges shipping port transportation transit center, as well as strengthen hinterland transport corridor.

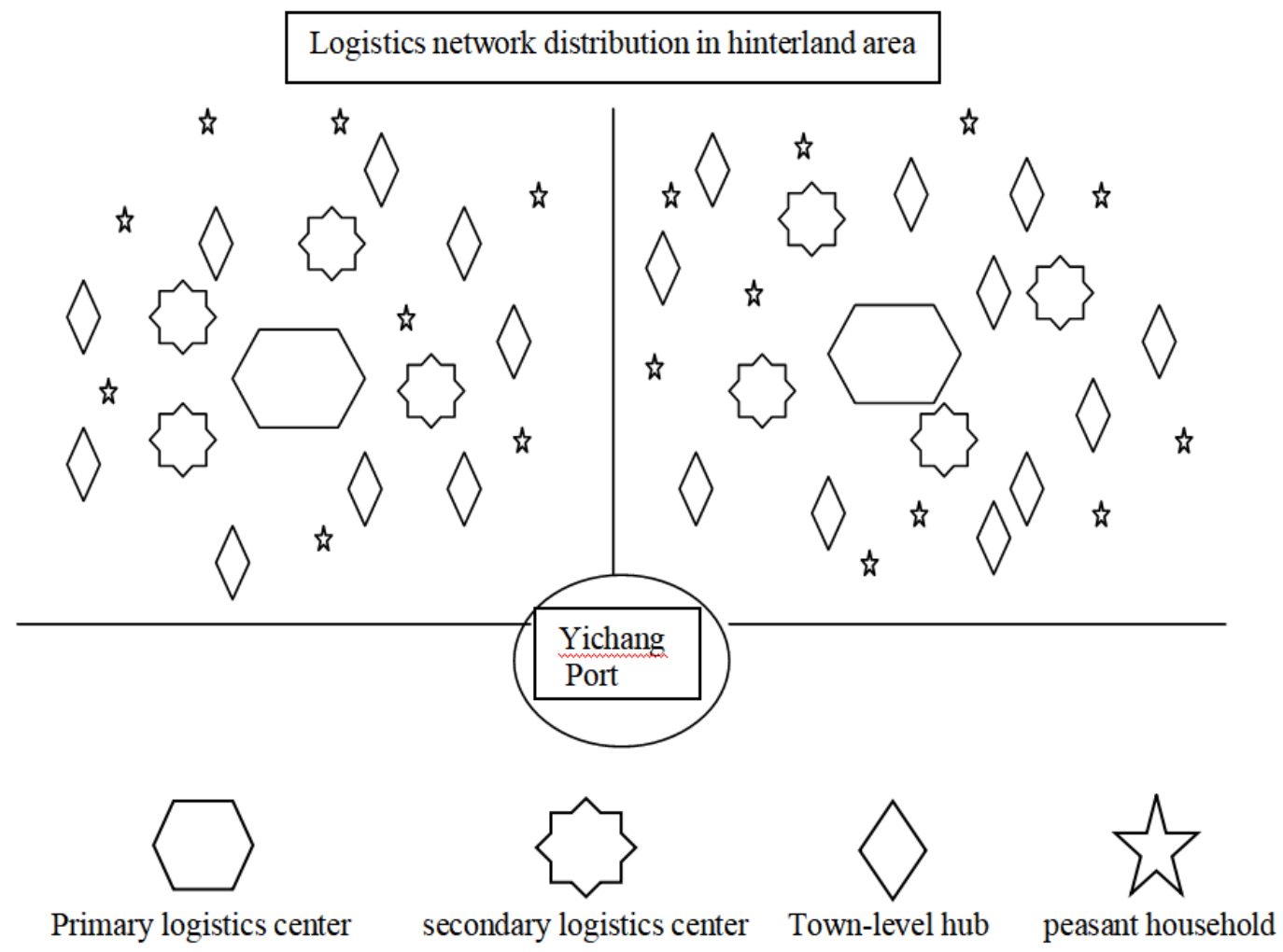

Fig.5

Through resource integration and strategic cooperation, Yichang port should build a logistics system with clear division of labors. Around the wide Yichang three gorges area, the economic development in various areas is unbalanced, and the industry is fragmented, as well as the agricultural 
proportion is large. According to these situation, at the time of constructing logistics system, The different levels and different division of labor should be divided. The transportation network should be optimized. And have their own characteristics to realize dislocation development. Taking agricultural products as an example, we can build a model as shown in figure 5 .

Among them, the relationship between primary logistics center, secondary logistics center and port is shown in table 5.

Table 5. The comparison among three different location types

\begin{tabular}{|c|c|c|c|}
\hline location type & Main functions & layout characteristics & $\begin{array}{c}\text { Advantages\&disa } \\
\text { dvantages }\end{array}$ \\
\hline $\begin{array}{c}\text { Port logistics } \\
\text { Industrial concentration } \\
\text { area }\end{array}$ & $\begin{array}{l}\text { Container, assembly, } \\
\text { packaging, processing, } \\
\text { information } \\
\text { management, storage }\end{array}$ & $\begin{array}{l}\text { There must be supports } \\
\text { of trunks and branches } \\
\text { of road, railway and } \\
\text { other trunk within the } \\
\text { primary logistics center }\end{array}$ & $\begin{array}{c}\text { Form the } \\
\text { advantages of } \\
\text { storage, } \\
\text { transportation } \\
\text { and processing } \\
\text { on a large scale, } \\
\text { integrate logistics } \\
\text { information, and } \\
\text { transport } \\
\text { comprehensively }\end{array}$ \\
\hline $\begin{array}{c}\text { Primary logistics center } \\
\text { Or community }\end{array}$ & $\begin{array}{l}\text { Bulk cargo, arrange } \\
\text { and allocate goods } \\
\text { Circulation processing, } \\
\text { refrigeration, etc }\end{array}$ & $\begin{array}{l}\text { There must be supports } \\
\text { of trunks of road, } \\
\text { railway within the } \\
\text { secondary logistics } \\
\text { center, and the } \\
\text { assemble system is } \\
\text { required }\end{array}$ & $\begin{array}{l}\text { The scale is } \\
\text { formed and the } \\
\text { strong delivery } \\
\text { capacity is } \\
\text { required }\end{array}$ \\
\hline $\begin{array}{l}\text { secondary logistics center } \\
\text { Or community }\end{array}$ & $\begin{array}{c}\text { Issue product } \\
\text { purchasing standards, } \\
\text { planting requirements, } \\
\text { transaction } \\
\text { specifications, } \\
\text { technical training and } \\
\text { feedback to customers }\end{array}$ & $\begin{array}{l}\text { Connect to the } \\
\text { scattered single } \\
\text { logistics functional } \\
\text { organizations (private } \\
\text { logistics, enterprises } \\
\text { and individuals), } \\
\text { distributed at the } \\
\text { township level }\end{array}$ & $\begin{array}{l}\text { Close to the } \\
\text { upstream of the } \\
\text { supply chain, it } \\
\text { can strengthen } \\
\text { the control of } \\
\text { products, and it } \\
\text { requires } \\
\text { information } \\
\text { sharing and } \\
\text { support }\end{array}$ \\
\hline
\end{tabular}

\section{References}

[1] Shen Run. Research on China's logistics industry cluster model, Logistics technology.2011 (13).

[2] Li Bin, Chen Changbin. Dynamic mechanism analysis on the formation and development of regional logistics industrial clusters, Commercial economy and management.2010 (07).

[3] Chen Yunping. Competitive advantages and forming models of logistics industrial clusters, Scientific and technological progress and countermeasures.2010 (21).

[4] Zhu Hui, Zhou Gengui, Ren Guoyan. Study on the spatial co-aggregation of manufacturing industry and logistics industry -- a case study of six provinces in central China, Economic geography. 2015(11).

[5] Yang Yan. Research on the coordinated development of port logistics and port industry, Wuhan University of technology. 2009. 